№ 28 (2019) стор. 136-141

The National Academy of Fine Arts and Architecture

Ukrainian Academy of Fine Art. Research and Methodology Papers

ISSN 2411-3034

Website: http://naoma-science.kiev.ua/

УДК 7 : 378.6](477.411)НАОМА

ID ORCID 0000-0002-3822-9674

DOI: https://doi.org/10.33838/naoma.28.2019.136-141

\author{
Ivan Pylypenko \\ Professor of the Department of Painting and Composition, \\ National Academy of Fine Arts and Architecture \\ ivpylyp@ukr.net
}

\title{
THE HISTORY OF ART WORKSHOP AND TEMPLE CULTURE OF THE NATIONAL ACADEMY OF FINE ARTS AND ARCHITECTURE
}

Absract. This article is dedicated to the studio of fine arts and temple culture in the context of the history of the National Academy of Fine Arts and Architecture. Analyzed was the educational program of the studio's founder, M. Storozhenko. Discovered were the methodological analogies between the studio of monumental painting and templar culture of NAFAA, M. Boychuck's art workshop and the icon-painting studio of the Kyiv Pechersk Lavra. It was proved that an analysis of historical experience can be useful in the educational process and in the upbringing of the modern painters of sacred (religious) art.

Keywords: M. Storozhenko, monumental painting workshop, educational process, education method.

\section{ІСТОРІЯ МАЙСТЕРНІ ЖИВОПИСУ І ХРАМОВОЇ КУЛЬТУРИ НАЦІОНАЛЬНОЇ АКАДЕМІЇ ОБРАЗОТВОРЧОГО МИСТЕЦТВА І АРХІТЕКТУРИ}

\section{Іван Пилипенко}

Анотація. Статтю присвячено майстерні живопису і храмової культури, де здійснюється підготовка художників, які спеціалізуються на релігійному станковому й монументальному живопису. Ретроспективний аналіз історії майстерні проведено на тлі історії Національної академії образотворчого мистецтва і архітектури. На основі вивчення історичного, організаційного та педагогічного досвіду цієї майстерні підтверджено, що академія від часу свого заснування зберігає традиції фахового навчання в індивідуальних навчально-творчих майстернях, очолюваних видатними митиями-педагогами, які самостійно формували навчальні програми, добирали методику та втілювали педагогічні ідеї у своїй викладацькій практиці. Проаналізовано програму засновника майстерні живопису і храмової культури професора М. Стороженка. Увагу акцентовано на поєднанні в ній двох складових: релігійномистецької культури та академічної фахової школи. Підкреслено, що засадничою ідеєю майстерні став стиль українського бароко. Збереження візантійсько-давньоруської образотворчої традиції через копіювання творів релігійного малярства разом із засвоєнням академічної програми з рисунка, живопису та композиції на сьогодні складають суть методики виховання майбутніх фахівців за спеціалізацією художник-живописець-монументаліст. Розглянуто значення навчального іконостаса та виконання спільного бакалаврського диплому, що дозволяє виховати у студентів вміння творчо працювати в колективі, дотримуватись колегіальної думки, підпорядковувати особистісне загальному, критично мислити. Виявлено методологічні аналогії між майстернею монументального живопису $і$ храмової культури НАОМА, майстернею М. Бойчука та іконописною малярнею Києво-Печерської лаври. Доведено, що використання традиції і практики, поєднання національних традицій з новаціями мистецтва першої третини XX ст. дозволили М. Стороженкові виробити свою методику викладання, свою педагогічну систему, започаткувати свою школу. Стверджено, що аналіз історичного досвіду може бути корисним у процесі навчання і виховання сучасних художників сакрального мистецтва.

Ключові слова: М. Стороженко, майстерня монументального живопису, навчальний процес, методика викладання. 
Problem formulation. Knowledge of the art education history allows seeing the regularities of the creation of faculties and specializations, to understand better the opportunities of educational methods regarding the professional disciplines, to learn a practical experience of the past in order to form a modern pedagogical system of the artist's education. Changes in the structure of NAFAA that took place during the years of Independence are corresponding with the spiritual needs of the modern times and are connected with the improvement of the educational process. The Academy is preparing professionals by both traditional and new specializations. The studio of painting and templar culture belongs to the latter and the students who are graduating from it are specializing in the religious easel and monumental art. Studying of historical, organizational, pedagogical and creative experience of this studio is advisable, considering the processes that are currently existing in the post-secondary art field.

The relevance of this study is conditioned by the absence of thorough research of the historical development of NAFAA that would include the history of the faculties, academic studios, study of the pedagogical activity of many famous artists and their educational methods. The Academy saves the tradition of teaching in various educational-creative studios, that are led by famous artists-educators, which are creating their own educational programs. The history of creation and the functioning of the studio of painting and temple art seems underexplored and requires both comprehensive study and retrospective analysis.

Connection of this research with important scientific and practical tasks. Revealed information can be used in further research of this topic, and should be a part of the NAFAA's general history. This article is written in accordance with the scientific-research work plan of the department of painting and composition of the NAFAA.

Analysis of the latest research and publication showed that contemporary Ukrainian art criticism looks into the problems that took place in the history of Ukrainian art education. Review of literature regarding the development of Ukrainian academic painting school of $20^{\text {th }}-$ beginning of $21^{\text {st }}$ century was conducted in the studies of O. Kovalchuk. Although the subject of foundation and function of NAFAA in general theory and in narrow profile as- pects was in the area of interest of many researchers (O. Kashuba-Volvach, M. Kryvolapov, L. Prybiega, R. Shmagalo etc.), the history of particular studious of the Academy is open for research. The attention of researchers was primarily concentrated on M. Boychuk's school, and accordingly, other studios were on the periphery of scholars' attention (V. Grygorov, I. Pylypenko). Short biographical facts regarding artists-educators one can find in reference publications, particularly about the founder of the painting and temple culture studio, M. Storozhenko. Multifaceted creativity of this artist is somewhat researched, but at the same time, his pedagogical activity still is little explored. An exemption is an analytical O. Solovey's article "Phenomena of artistic-pedagogical activity of professor Mykola Storozhenko" (2009), which shows the aspects of pedagogical practice of studio's head, and the features of the educational program. Publications in the periodical press, interviews with M. Storozhenko have a factual component, yet are descriptive, not critical. Basis of the current study are materials, collected by the author from his student times until now. Therefore, the bibliography review shows that the history of painting and temple culture studio have not found proper coverage in the field of art criticism.

Annotation of previously unresolved parts of the general problem, addressed by this article. Retrospective analysis of the history of NAFAA's painting and temple culture studio, which prepares specialists of the religious easel and monumental art, constitutes this article's main objective.

The novelty of scientific research is that comprehension of the history of NAFAA's painting and temple culture studio and finding historical analogies can be a foundation for contemporary models of artistic reforms.

Methodological or general scientific value of the author's research is conditioned by a complex approach to the analysis of the development of NAFAA's painting and temple culture studio. Properly applied methods of archive and bibliographic search, factual-descriptive method, method of historical and cultural analysis, method of factual material generalization.

Presentation of the main material. The National Academy of Fine Arts and Architecture (NAFAA) is the oldest visual-arts post-secondary institution 
in Ukraine. During the last hundred years, the institution changed its status several times: Ukrainian Academy of Arts, Institute of Plastic Arts, Kiev Art Institute, and Academy of Fine Arts and Architecture. Hence, some important changes have been made in the curriculum, academy structure, academy programs, and teaching style. These changes were important in student's professional learning.

Today the Department of Painting and Composition prepares students of the easel and monumental painting by specialization: painter and paintermuralist. In particular, monumental artists study in the workshop of monumental art. Since 1994 the students can also study in the new educational and creative workshop of monumental painting and temple culture.

Modern art in the forms of sacred monumental art brings us back to the time of the foundation of the Ukrainian Academy of Arts in December of 1917. One of the academy's founders, Professor Mikhailo Boychuk, created and led the workshop of religious painting, mosaics, murals and icons, which in the short time was renamed into The Monumental Painting Workshop (Kovalchuk 91). The 1920s was a rising time of monumental art. Subsequently, two more workshops were created: the monumental-decorative painting workshop by Professor Lev Kramarenko and the mosaic workshop of Professor Andriy Taran. The desire of these masters to combine the traditions of Byzantine and ancient Ukrainian art with the latest discoveries of European art created conditions for creative learning of the traditions of monumental art. They actively experimented, introduced new pedagogical concepts, conducted classes on colour, volume and space, provided creative formal and technical tasks.

The basis of Boychuk's pedagogical system was the development of skills that are important for future monumentalists, as well as the combination of theory and practice including both individual and group learning. Also, studying the principles of constructing compositions and colouring of different art periods and schools by performing exercises - graphic analyzes of outstanding works of the past, mainly the art of Byzantium, Kievan Rus, Proto-Renaissance and folk art.

The system of national arts education changed dramatically as a result of the reform of 1934. The centralization of educational programs of profession- al disciplines, the revival of the academic system of education, the obligatory observance of the unified program of the All-Russian Academy of Arts required an appropriate adjustment of the content of the curriculum, the unification of teaching methods that fully corresponded to the ideology of that time.

The easel forms of art became a priority. Since 1934, the specialization of "monumental art" in general ceased to exist and was restored only after 1963 (Chebykin 11). At various times, the updated studio of monumental painting was headed by Professors Vilen Chekanyuk, Tetyana Yablonska, Oleksiy Kozhekov (since 2000).

Since the beginning of the 1990s, the revival of church art has taken place in Ukraine. The construction and restoration of religious buildings revealed the urgent need for the training of arts personnel who would be professionally prepared to create new and restore old temples, in order to keep the traditions of visual art in general and religious art culture in particular. This task was faced not only by architects but also by artists of monumentalism. The complexity of the training program was that a new generation of painters should have a solid understanding of art decoration, be professionally aware, and possess the full range of technological skills. In addition, they should have received a deep knowledge of the religious canons, and be acquainted with the specifics of art complexity. Christian temples are very unique, where architecture, interior decorations are subject to the theological program in synthesis with the liturgical action.

The solution to such a complex task has become possible in the educational and creative workshop of painting and temple culture. Since 1994, it has been training highly skilled artists who can express themselves as temple painters in decorating iconostases and interiors of temples, as well as capable of creating religious-historical easel paintings. The new workshop became the preparation base of the fine arts faculty specialization and allowed the artists of temple painting to gain an independent professional status in the system of national fine arts. Professor Mykola Storozhenko (1928-2015), painter, graphic artist, full member of the Academy of Arts of Ukraine, People's Artist of Ukraine, Taras Shevchenko State Prize winner, member of the National Union of Artists of Ukraine, who developed the concept of the workshop, carried out a scientific- 
methodical and creative provision of teaching the relevant disciplines in the developed curriculum.

Some analogies can be found between the monumental painting workshop and the temple culture of NAFAA, workshop of M. Boychuk, and the icon painting of the Kyiv-Pechersk Lavra. Such as the method of teaching combining practice and theory, and separate elements of the academic system of learning and copying. This is evidenced by the Kuzbushky preserved in the Lavra library - handcrafted albums, consisting of separate sheets of drawing atlases and academic manuals, engravings of Kyiv and Western masters and students' copies (Zholtovsky).

The founder of the workshop and its head, professor M. Storozhenko, developed his own program, outlining the direction of the workshop and identified it and methods of teaching. The combination of the two components, the religious-artistic culture and the academic high school of specialty, led to the reorientation of professional disciplines, as well as an introduction to the curriculum of special disciplines. The specialization of students takes place in the third year and ends with the completion of the thesis. Today, the teachers of the workshops see the irprimary tasks in the revival of the abandoned traditions of temple painting, the studies of the sacred art history(Byzantium, Kievan Rus, the Ukrainian Baroque), the mastering of the academic program (drawing, painting, composition) and copy-religious program (copying works of religious painting), which is fixed by the practical work of students.

In the program, developed by M. Storozhenko the task to prepare highly professional artists is closely related to the upbringing skills of finding a practical solution to the problem of synthesizing genres and types of temple visual art. Creation of a harmonized and complete ensemble demands from the artists who create it a collective solution and a subordination of an individual vision of each performer to the main project (general idea). For the purpose of developing such a skill, M. Storozhenko proposed to involve future Bachelors of Fine Arts to work on the iconostasis. In order to do that, he designed a training iconostasis $3 \times 6$ meters, which is compositionally close by its style and composition to the wood-carved Ukrainian baroque iconostasis of the $17^{\text {th }}$ century. It consists of five rows (levels), fitted into rectangular frames: Basis, Sovereign, Feasts, Twelve Apostles and the finishing in the shape of medallions in carved frames. Iconostasis contains many icons of different sizes (from miniatures in the Beautiful Gates to the icons more than two meters in height).

This project on the joint bachelor's degree starts at the beginning of the 4th year. Each of the future performers presents their individual sketch of the iconostasis. Students are electing the best one among them by secret ballot, and they will work on it together, coordinating the color scheme, stylistic and compositional solution.

After that, they are choosing the icons that they will paint personally with the mandatory abidance to the general idea and to the opinion of the whole collective. A student has a choice to make either one large icon or a few smaller ones. Implemented by the studio's founder approach to the realization of the collective task through individual work contributes to the skills of creative coworking, subordinating the personal to the general, making collective decisions, creating dialogs, and critical thinking. This experience is useful when students will be working on real, actual projects. There are such examples in the studio's history.

In 1999 practical component of the studio's program reached a qualitatively different level. M. Storozhenko brought back to life M. Boychuk's guidelines, that consisted of a skillful combination of theory and practice, both individual and collective, and therefore went a long way with his students from the academic school to the scaffold, on the walls of real buildings. In 1999, that was St. Mykola Prytyska church (Kyiv), where students (S. Gerasymentko, O. Kriukov, D. Savchenko, O. Tsugorka) and professor's assistants (V. Nedaiborsch, O. Solovey) completed sacred murals on the church's wall alongside with the professor.

That tradition of realizing graduation projects of the studio's graduates-to-be was continued. Few examples: in Staropetrivtsi village students and assistants created an iconostasis (M. Guyoviy, O. Gurtova, V. Nedaiborsch, O. Solovey, N. Tsymbaliuk); tempera murals on the walls of Pokrovska church in Sevastopol was made by a postgraduate, V. Kozyk. Since 2011 in St. Michael's cathedral, located in Zhytomyr paintings are underway, curated by studio's graduate D. Belianskiy with student's involvement; for instance, master degree's artworks of G. Andrusenko "The Tower of Babel”, A. Kovalen- 
ko "The Deluge", and A. Osadchuk "The Miracle of St. Gregory".

Well-known currently master of icon painting, docent of the studio O. Tsugorka developed a concept, and with his fifth-year students designed Mykola Storozhenko's Memorial Museum in his home village Vyazevo in Sumy region, which was opened in September of 2018.

Combination of national, in particular - baroque traditions with innovations of Ukrainian art of the beginning of 20th century allowed M. Storozhenko to develop his pedagogical system, his method of artist's education, to create his school of sacred art professionals. M. Storozhenko's school is certain soundness of thinking and ideological principles, that are multiplied by a high skill of craftsmanship and methods of continuous self-improvement.

Conclusion. Retrospective analysis of the history of NAFAA's painting and temple culture studio allows tracing the way of its development, to comprehend its achievements, pay respect to the professors that laid the foundation of the school of academic religious painting. At the same time, this studio's history lets one grasp the big picture of Ukrainian monumental art school's development. There have been found certain analogies in methodological approaches and the combination of theory and practice between the studio of monumental painting and temple culture, M. Boychuk's studio, and the icon-painting studio of Kyiv-Pechersk Lavra. The search for historical analogies may be a foundation for contemporary models of artistic reforms.

Today, the National Academy of Fine Arts and Architecture retains the principles of study, started in 1917. Future artists receive professional training in individual educational and creative workshops. In particular, the temple painting workshop is designed to carry out the creative and professional synthesis of the millennial sacred experience and the centennial Kyiv school of academic and secular art, to direct personal way in the creativity of the future artist.

Prospects of application of this study's results. Materials, suggested in this article would be useful when writing generalizing materials regarding Ukrainian art history, the formation of national painting school, and can also be used in the educational process when preparing lectures, methodological and educational tutorials for the students of art colleges and universities.

\section{Цитовані праці}

Григоров, Віктор. “Відновлення та робота майстерні монументального живопису київського художнього інституту в 60-80-х роках XX ст.”. Українська академія мистецтва : Дослід. та наук.метод. пр. (26) 2017: 277-283. Друк.

Жолтовський, Павло. Малюнки Києво-Лаврської іконописної майстерні. Київ: Наукова думка, 1982. Друк.

Кашуба-Вольвач, О. Українська академія мистещтва: Історія заснування (березень-грудень 1917). Хронологія подій. Документи. Київ: Фенікс, 2014. Друк.

Ковальчук, Остап. “Українська академічна художня школа другої половини XX - початку XXI ст.”. Українська академія мистецтва : Дослід. та наук.-метод. пр. 18 (2011): 86-95. Друк.

Криволапов, Михайло. "Українська академія мистецтва. Сторінки історіі” Мистецтвознавство України : Зб. наук. пр. 6-7 (2006): 511-530. Друк.

Прибєга, Леонід. “Історія і сьогодення Національної академії образотворчого мистецтва і архітектури”. Українська академія мистещтва: Дослід. та наук.-метод. пр. (14) 2007: 12-23. Друк.

Соловей, Олесь. “Феномен творчо-педагогічної діяльності”. Мистецтвознавство України : Зб. наук. праць. 9 (2008): 338-345. Друк.

Чебикін, Андрій. “Українська академія мистецтва: традиції, сучасність, перспективи”. Українська академія мистецтва : Дослід. та наук.-метод. пр. 1 (1994): 9-15. Друк.

Шмагало, Ростислав. Мистецька освіта в Україні середини XIX - середини XX століття: структурування, методологія, художні позиції. Автореф. дис. Львів. нац. акад. мистецтв. 2005. Львів. Друк.

\section{References}

Gry'gorov, Viktor. "Vidnovlennya ta robota majsterni monumental'nogo zhy’vopy'su ky'yivs'kogo xudozhn'ogo insty'tutu v 60-80-x rokax XX st.”. Ukrayins'ka akademiya my'stecztva : Doslid. ta nauk.metod. pr. (26) 2017: 277-283. Druk. 
Zholtovs'ky'j, Pavlo. Malyunky' Ky'yevo-Lavrs'koyi ikonopy'snoyi majsterni. Ky'yiv: Naukova dumka, 1982. Druk.

Kashuba-Vol'vach O. Ukrayins'ka akademiya my'stecztva: Istoriya zasnuvannya (berezen'-gruden' 1917). Xronologiya podij. Dokumenty'. Ky'yiv: Feniks, 2014. Druk.

Koval'chuk, Ostap. “Ukrayins'ka akademichna xudozhnya shkola drugoyi polovy'ny' XX - pochatku XXI st.”. Ukrayins'ka akademiya my'stecztva : Doslid. ta nauk.-metod. pr. 18 (2011): 86-95. Druk.

Kry'volapov, My'xajlo. “Ukrayins'ka akademiya my'stecztva. Storinky' istoriyi” My'stecztvoznavstvo Ukrayiny' : Zb. nauk. pr. 6-7 (2006): 511-530. Druk.

Pry'byega, Leonid. "Istoriya i s'ogodennya Nacional'noyi akademiyi obrazotvorchogo my'stecztva i arxitektury". Ukrayins'ka akademiya my'stecztva: Doslid. ta nauk.-metod. pr. (14) 2007: 12-23. Druk.

Solovej, Oles'. "Fenomen tvorcho-pedagogichnoyi diyal'nosti”. My'stecztvoznavstvo Ukrayiny' : Zb. nauk. pracz'. 9 (2008): 338-345. Druk.

Cheby'kin, Andrij. "Ukrayins'ka akademiya my'stecztva: trady'ciyi, suchasnist', perspekty'vy'”. Ukrayins'ka akademiya my'stecztva : Doslid. ta nauk.-metod. pr. 1 (1994): 9 - 15. Druk.

Shmagalo, Rosty'slav. My'stecz'ka osvita v Ukrayini seredy'ny' XIX - seredy'ny' XX stolittya: strukturuvannya, metodologiya, xudozhni pozy'ciyi. Avtoref. dy's. L'viv. nacz. akad. my'stecztv. 2005. L'viv. Druk.

Подано до редакції 20.06.2019

\section{Рецензенти:}

Ключко Ю. М. - кандидат педагогічних наук, доцент;

Белічко Н. Ю. - кандидат мистецтвознавства, доцент. 